Chinese Environmental Contention 


\section{China's Environment and Welfare}

China's environmental challenges are an issue of global concern. This however has meant that in much writing on the topic 'the environment' has become equated with 'pollution'. In similar ways, the study of welfare has become synonymous to the study of illness. This book series champions a broad analytical rethinking of these terms, and encourages explorations of their complex interconnections. Practices under scrutiny may range from fengshui and hygiene to farming, forest governance, mining and industry. Topics may be equally wide-ranging, spanning from climate change, waste incineration and cancer villages to everyday environmentalism and cultural and ritual engagements with environment and welfare.

Geographically, the series covers rural and urban areas as well as their growing hybrid meeting point. Interdisciplinary in scope, the series will feature disciplines from across the social science and humanities, including anthropology, sociology, geography, development studies and political science. As a whole, the series promotes a conception of welfare which positions human welfare as part of broader ecological welfare and probes human-ecological interactions. It will make an excellent contribution to the study of China by significantly improving understanding of these major topics and redefining them in a creative and innovative way. The series will also contribute to key debates in Chinese studies on state legitimacy, agency and social change through a close study of these topics.

\section{Series Editor}

Anna Lora-Wainwright, School of Geography and the Environment, University of Oxford

\section{Editorial Board}

Mikkel Bunkenborg, University of Copenhagen

Jane Duckett, University of Glasgow

Sarah Eaton, University of Göttingen

Mette Halskov Hansen, University of Oslo

Michael Hathaway, Simon Fraser University, British Columbia

陆继霞 Lu Jixia, China Agricultural University, Beijing

Genia Kostka, Free University of Berlin

Ralph Litzinger, Duke University, Durham

Nicholas Loubere, Lund University

Fengshi Wu, University of Melbourne

Guobin Yang, University of Pennsylvania

Heather Zang, University of Leeds 


\title{
Chinese Environmental Contention
}

\author{
Linking Up against Waste Incineration
}

Maria Bondes 
Cover illustration: Gaoantun incinerator, Beijing, November 2012

Source: Maria Bondes

Cover design: Coördesign, Leiden

Lay-out: Crius Group, Hulshout

ISBN $\quad 9789462988927$

e-ISBN $\quad 9789048541331$ (pdf)

DOI $\quad 10.5117 / 9789462988927$

NUR $\quad 761$

(C) Maria Bondes / Amsterdam University Press B.V., Amsterdam 2019

All rights reserved. Without limiting the rights under copyright reserved above, no part of this book may be reproduced, stored in or introduced into a retrieval system, or transmitted, in any form or by any means (electronic, mechanical, photocopying, recording or otherwise) without the written permission of both the copyright owner and the author of the book.

Every effort has been made to obtain permission to use all copyrighted illustrations reproduced in this book. Nonetheless, whosoever believes to have rights to this material is advised to contact the publisher. 